\title{
Ornamento a graffito delle facciate. La rappresentazione dell'Architettura sull'Architettura
}

\author{
Daniele Giovanni Papi \\ Franco Forzani Borroni \\ Francesca Di Geronimo
}

Abstract

La completa schedatura dei paramenti ornamentali a graffito dei palazzi di Pienza (fig. I) è stata preceduta dalla ricerca specifica degli elementi di valutazione e catalogazione necessari.

II rilievo diretto e il ridisegno hanno poi condotto a una tesi di laurea magistrale già discussa e a pubblicazioni in corso di editazione sulla terminata e completa schedatura delle facciate della città. In questo paper si rende conto degli studi preliminari condotti.

Da letteratura e documentazione si evince quanto nella Toscana del Rinascimento le facciate affrescate fossero meno apprezzate di quelle graffite, anche a fronte di una maggiore padronanza della tecnica da parte degli esecutori, della durabilità nel tempo e della rapidità di realizzazione. In seguito, spesso e inspiegabilmente considerate semplici strati di protezione, anziché vere e proprie opere d'arte e d'architettura, queste superfici sono state spesso trascurate nella manutenzione o addirittura ricoperte da intonaco uniforme. Pressoché ignorate dalla storiografia, la perdita di molte fra esse si è verificata prima che un corretto processo di documentazione e salvaguardia fosse definito, con la sola sensibilità dei proprietari degli immobili a portare con sé responsabilità e onere di tutela.

L'auspicio ultimo della schedatura dei palazzi pientini, nel tentativo di ricondurre il tema della facciata a graffito alla possibilità di una lettura critica, è riportare il tema a dignità di argomento di studio, mai esplicitamente negata, ma certo sminuita, in secoli di disattenzione (fig. 9).

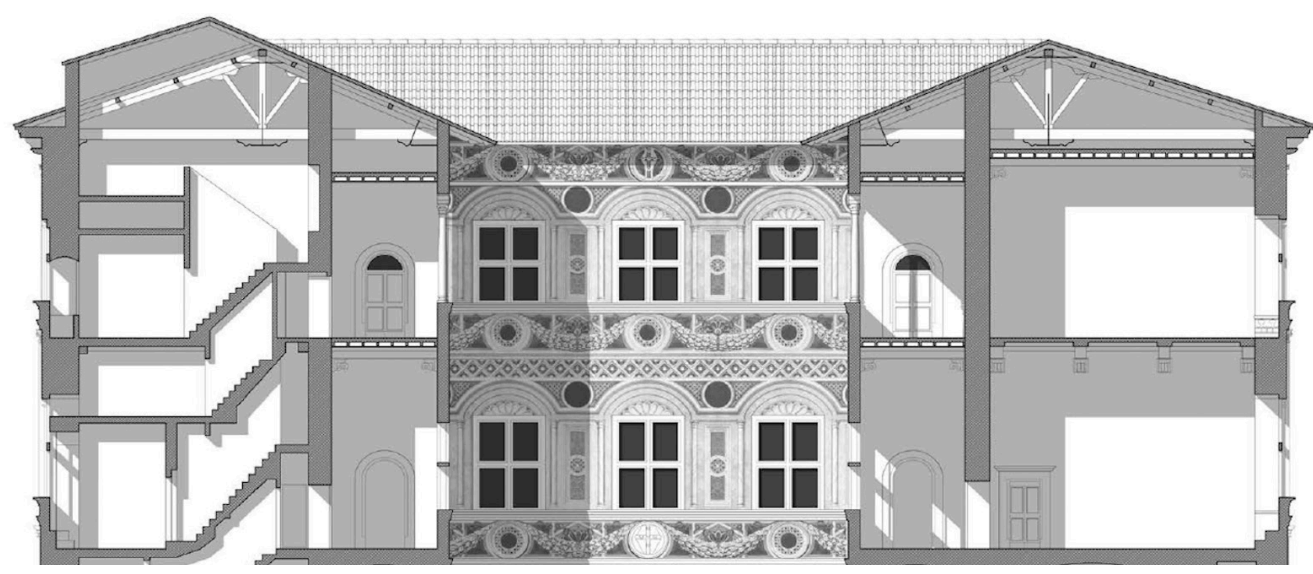




\section{Note sull'ornamento delle facciate dopo il Medioevo}

Dal Quattrocento in avanti, la particolare cura nell'esecuzione delle facciate diventa una cifra stabile, specie in rapporto alle nuove progettazioni urbane. In questo clima culturale la visione geometrico-formale di stampo toscano si arricchisce di effetti grafici fino a quella sintesi del tardo Rinascimento, tra plasticità scultorea e tessuto bidimensionale, secondo quel movimento che Panofsky chiama la "ribellione dei non architetti" [Panofsky 1962, pp. $223,224]$.

II colore non è inteso come 'materia che ricopre la facciata', ma come l'elemento che trasforma il palazzo in un testo di lettura destinato alla città, testimonianza della grandezza e del prestigio della famiglia che lo occupa.

La tipologia iconografica è spesso ripetuta, quasi esista un canone di decorazione per soggetti. Questo è dovuto in realtà alla scoperta e alla diffusione dei motivi 'a grottesche', diventati di moda nel corso del Rinascimento. Fra i pittori che più da vicino studiano il fenomeno, è soprattutto il fiorentino Filippino Lippi (I457- I504), che tra il I 487 e il I 502 traspone queste scoperte negli esuberanti apparati decorativi dei suoi più famosi cicli di affreschi. Le sue orme sono seguite da Andrea di Cosimo Feltrini (1477- I548) al quale spetta il primato del graffito in bianco e nero per le composizioni a grottesche, nelle quali coniuga l'energia formale di Filippino e la vibrazione chiaroscurale propria della pittura antica. Nella seconda metà del Cinquecento - e sempre in ambiente fiorentino - il maggior specialista nel campo di questo ornato 'all'antica' può considerarsi Bernardino Barbatelli (I548- I 6 I 2), soprannominato volta a volta "il Poccetti", Bernardino delle Facciate o Bernardino delle Grottesche, artista formatosi nella cerchia delVasari, il cui estro decorativo si esercita tanto nella grottesca dipinta quanto in quella graffita.

Nel Seicento, sulla scia del clima postconciliare, questa decorazione cade in disuso per i contenuti profani. Negli ultimi decenni del Settecento, con il revival della pittura pompeiana, esso riappare in forme diverse dalla grottesca tradizionale, esibendo fedeltà iconografica e

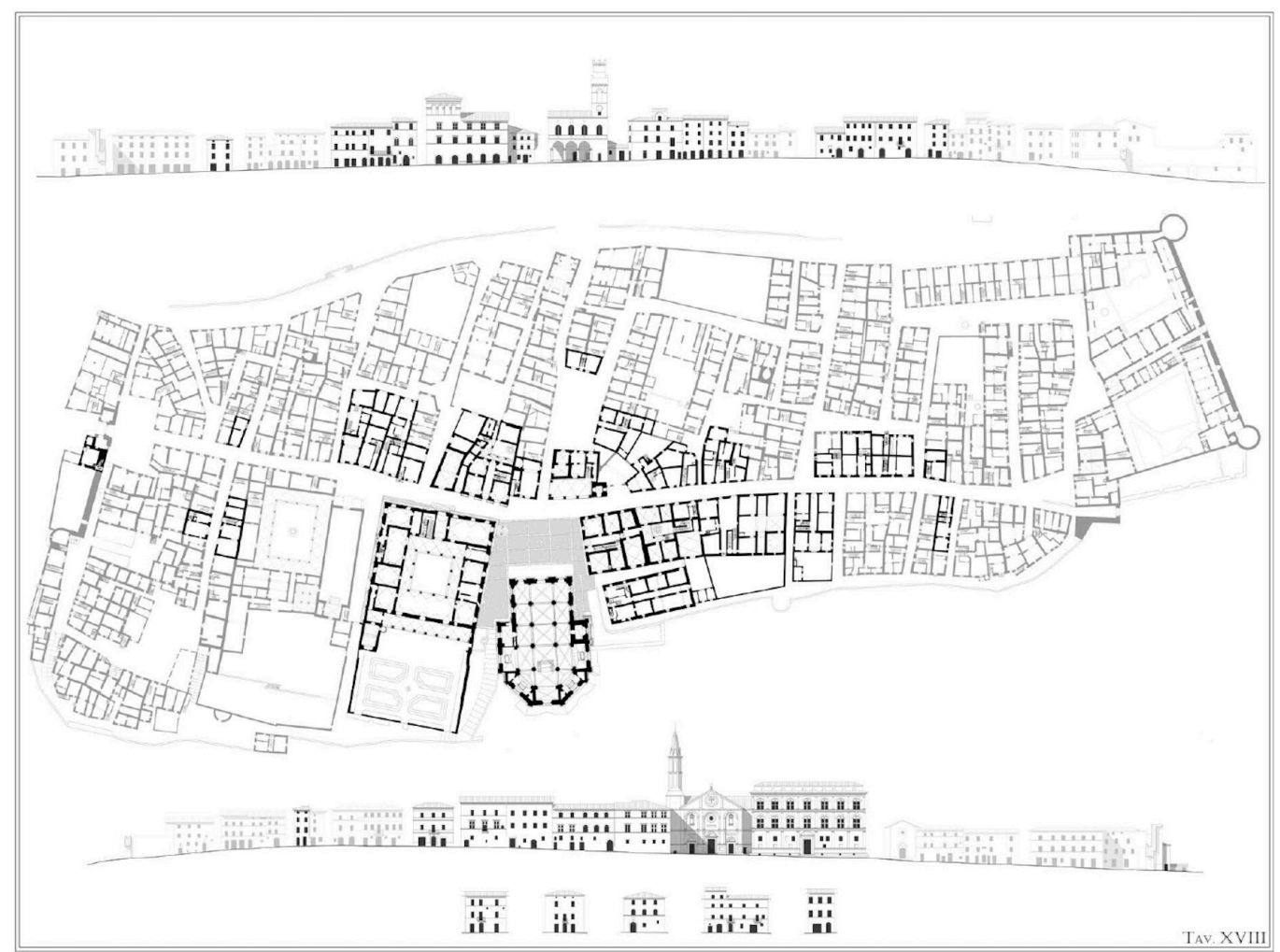


stilistica nei confronti degli originali. Ancora una differente versione della grottesca si afferma durante l'Ottocento, in sintonia con le istanze storicistiche del Romanticismo. Con l'intenzione di rivalutare il passato e di riproporne gli aspetti figurativi come simbolo di continuità morale e culturale, l'Ottocento ricorre all'imitazione degli ornamenti rinascimentali dei grandi maestri. Nelle città di più viva tradizione decorativa, i palazzi pubblici e privati, le banche, gli uffici, offrono ancor oggi un vasto campionario di composizioni a grottesche risalenti al XIX secolo.

Un'ultima trasformazione di questo genere decorativo ha luogo nel secondo Ottocento, in corrispondenza dello sviluppo dell'architettura eclettica, quando il riferimento ai modelli tradizionali si manifesta nella simmetria della composizione, discostandosene nell'aspetto d'insieme delle decorazioni.

\section{Tecniche di finitura superficiale}

"La figura qui davanti segnata è d'opera corintia la quale in parte si dimanda cruda e confusa in quella parte dove sono le colonne di pietra mista, e oscura perché la cosa di relievo essendo oscura viene a fare contrario effetto sopra la cosa chiara. Per questa ragione gli ottimi pittori dipingendo qualche istoria o favola, dove intervengono più figure, una dopo l'altra, fanno sempre le figure più vicine agli occhi nostri di colore più chiaro per dare più forza all'opera sua. E se altrimenti facessero cioè facendo la figura più vicina di colore oscuro e le più lontane di colore chiaro, e l'opera loro sarebbe cruda e confusa. Ciò avviene nell'opera qui davanti per le ragioni sopradette. Ma non voglio però che l'architetto rifiuti le colonne di pietra mista oscura né di porfido e serpentino, né tante belle e diverse incrostazioni. Anzi se ne serva grandemente ma con buon giudicio" [Serlio I584, Libro VII, p. I26]. II passo riportato, posto a commento di un'illustrazione del settimo dei Libri dell'architettura di Serlio, testimonia l'interesse degli architetti rinascimentali per il materiale: l'uso e la scelta

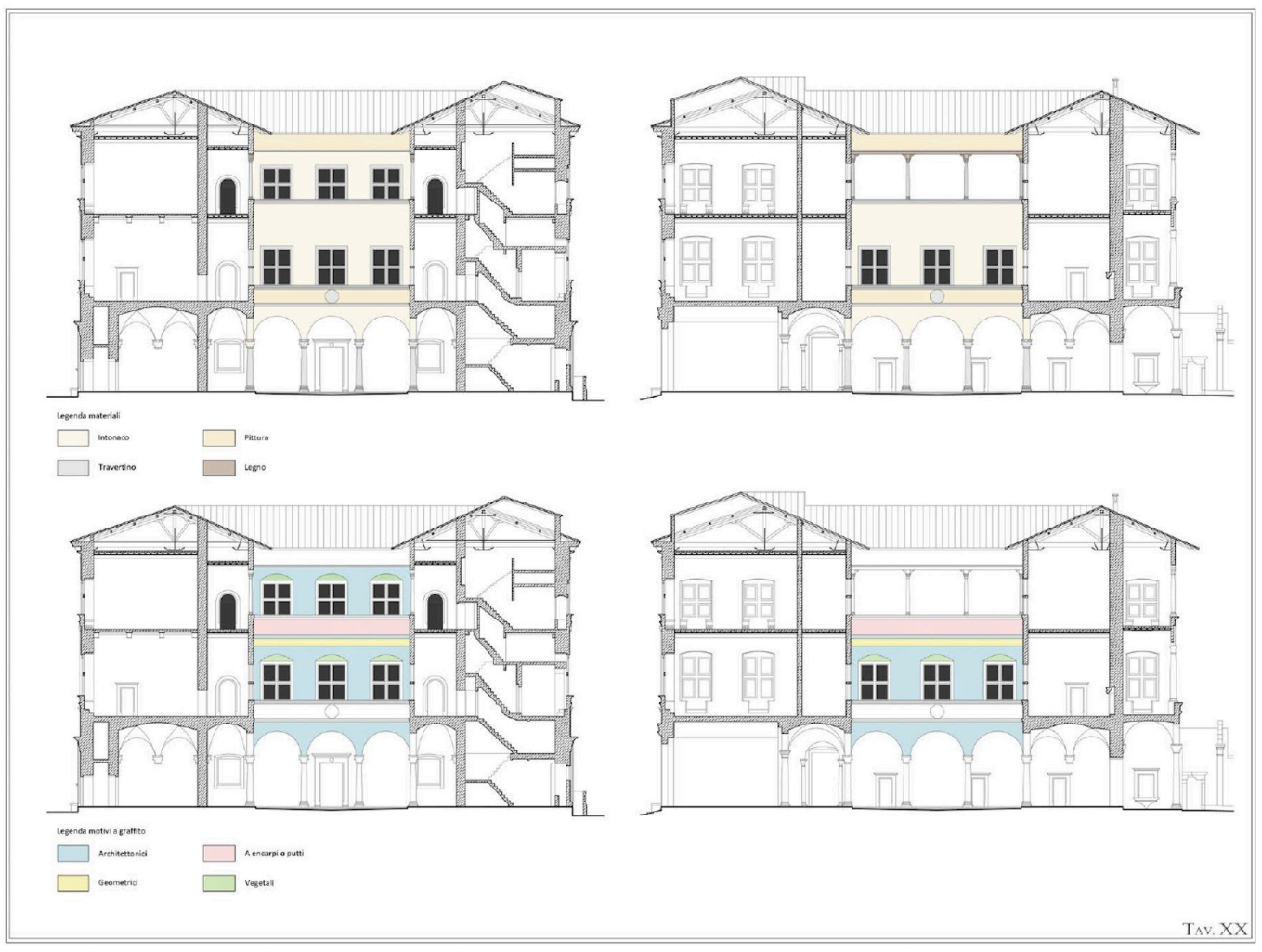


di materiali specifici comporta la definizione cromatico-visiva dell'opera, direttamente derivata dall'intenzione del suo progettista. Inoltre, poiché ogni aspetto della cultura del Cinquecento va messo in relazione con l'antico (e in particolare con la conoscenza che dell'antico si aveva all'epoca), l'analisi parte dagli studi condotti a quei tempi sui monumenti del passato, attraverso l'esame dei disegni di antichità romane e della trattatistica: entrambi mostrano interesse sia per le tecniche costruttive in generale, sia per le tecniche di imitazione e contraffazione di alcuni materiali.

L'esecuzione dei disegni registra anche il gusto per l'aspetto di alcuni materiali e la censura sistematica di altri - il peperino, i tufi e i laterizi - reputati adatti a un ruolo esclusivamente costruttivo [I]. Dalla riproposizione del gusto degli antichi romani, scaturisce l'aspirazione rinascimentale a un'architettura in pietra e - là dove l'uso della muratura in mattoni si sostituisce ai conci - spetta all'intonaco il compito di dare l'impressione dell'unitarietà costruttiva ed estetica: il rivestimento superficiale non possiede più solo una funzione protettiva, come nel Medioevo, ma si fa parte integrante del disegno di facciata, imitando la pietra o altri elementi architettonici. Sull'intonaco, tra l'altro, non è necessario applicare coloritura, in alcuni casi sono i segni della gradina, la graffitura a blocchi o a conci, a rendere credibile l'imitazione della pietra. Grazie a simili espedienti le esigenze espressive dell'architettura si giovano di una nuova sintesi tecnica che realizza in pietra solo le parti dell'ordine, inserendole poi nelle cortine laterizie - economicamente più convenienti - e contraffacendole infine con il rivestimento superficiale.

Alcuni documenti ritrovati e studiati nel tempo hanno fatto supporre che la cortina laterizia con cui il Bramante realizza il cortile del Belvedere fosse originariamente coperta di stucco [Forcellino 1988]: un disegno attribuito a Pirro Ligorio e conservato presso l'Istituto di Archeologia e Storia dell'Arte di Roma, mostra le facciate del cortile coperte da un bugnato che si suppone in stucco. All'Archivio di Stato di Roma sono depositati i documenti relativi alla realizzazione di parte di tale rivestimento, del quale oggi non rimane più alcun segno, nei quali si può leggere:"M.ro Raffaello da Sangallo stuccatore deve adì 2 di giugno 1565 sc. 
Ottanta havutone mandato a buon conto del lavoro di stucco cominciato da lui nell'emiciclo di belvedere $[\ldots]$ alla cornice dorica del primo ordine che continua el corritore vecchio et nella faccia di muro sopra i podi circolari" [2].

Tra le cortine laterizie ricoperte dallo stucco in finta pietra ci potrebbero essere anche quelle del Palazzo della Cancelleria, che in un disegno di Alessandro Specchi compare con le facciate rivestite da bugnato. Tale rivestimento potrebbe essere stato realizzato in stucco solo sui lati del palazzo - meno visibili - laddove la facciata principale era realizzata invece in vero travertino.

Anche la Farnesina di Baldassarre Peruzzi potrebbe essere letta in modo differente, se si ipotizzasse un leggero strato di finta pietra steso sulle lesene che oggi appaiono costituite solo da mattoni: è infatti poco probabile l'esibizione voluta degli elementi costruttivi, soprattutto considerando il disprezzo per il laterizio che Peruzzi annotò più volte nei suoi disegni. Si potrebbe dunque sostenere che la presenza di cortine murarie non esclude la possibilità che, a finitura delle stesse, vi fosse la rappresentazione di un'architettura realizzata in pietra viva. Per quanto riguarda il costruito in muratura ordinaria invece, non vi è alcun dubbio che la sua finitura fosse a intonaco, che in questi casi si rendeva indispensabile.

\section{II graffito}

Le facciate a graffito o dipinte ebbero un ruolo predominante nella definizione della scena urbana rinascimentale. Serlio spiega come queste tecniche fossero volte all'imitazione:

"Ma se con giudicio saldo si vorrà ornar con i pennelli una facciata si potrà fingere di marmo o d'altra pietra, sculpendo in essa ciò che si vorrà" [Serlio I584, Libro IV, p. 192].

Le facciate graffite e dipinte sono tra il Quattrocento e il Seicento una delle manifestazioni più rappresentative della cultura artistica italiana, che caratterizza, con differenti declinazioni, il paesaggio urbano di città come Roma, Firenze, Genova, Trento, Verona, Mantova, Pienza.
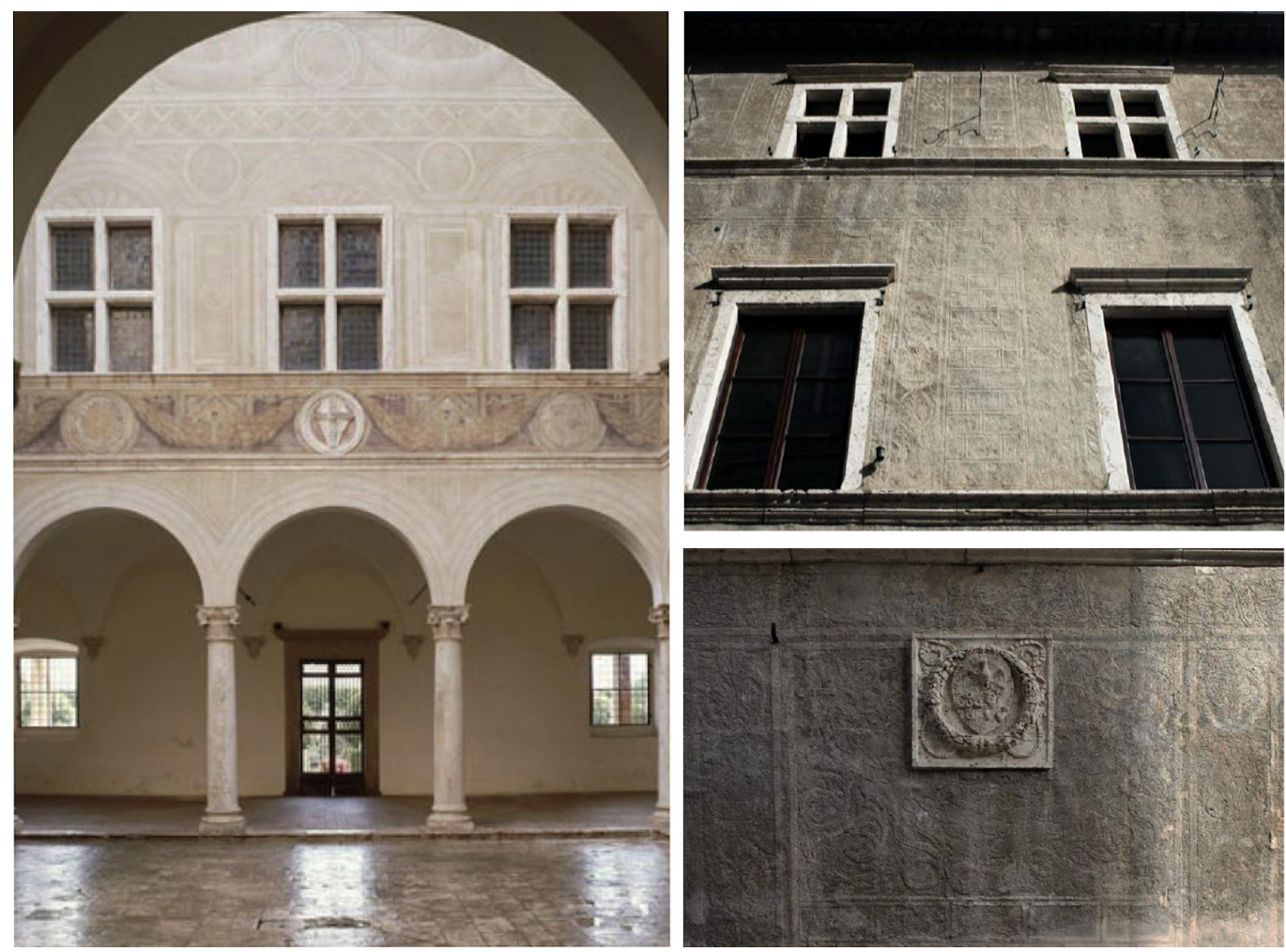
Nel suo primo trattato del I537, Serlio cita le facciate dipinte [Serlio I584, Libro IV, pp. I92, 193], ma le presenta come alternative a buon mercato delle facciate in pietra, con ciò condannandole al ruolo di Architekturersatz, elementi architettonici privi di particolare valore. Secondo l'autore, la pittura nuoce alla percezione della massività dei muri, che sembrano diventare trasparenti e sparire, e sconsiglia di dipingere a colori, raccomanda il chiaroscuro e rinvia alla pittura in grisaille, che imita il marmo, la pietra e il bronzo, e migliora l'effetto plastico della facciata. Ammette la rappresentazione di festoni di foglie, di fiori e di frutta, di trofei di armi e apparati trionfali che si potrebbero appendere ai muri. II colore non è permesso, a meno che gli oggetti rappresentati non siano rimovibili, ad esempio stoffe fissate al muro, sulle quali si potrebbe dipingere senza perturbare l'ordine architettonico. Sono in effetti questi i motivi di gran parte della decorazione a graffito, che però Serlio non menziona.

A Firenze, e in Toscana in generale, la facciata a graffito conosce popolarità costante. Più comune fuori dalla Toscana è il chiaroscuro, simile al graffito e generalmente associato a Polidoro da Caravaggio ( I 499/I 500- I 543) e a Maturino da Firenze (I 490- I 528), che ne fanno una moda a Roma prima del sacco del I527, e che si fa desueto dopo la morte di Polidoro. Nondimeno, questa variante di facciata in grisaille dipinta, essenzialmente figurativa, non ha successo a Firenze, o almeno non più delle facciate dipinte (Palazzo Mellini-Fossi e Palazzo dell'Antella). Per secoli, la scelta preferita dei toscani è la facciata a graffito.

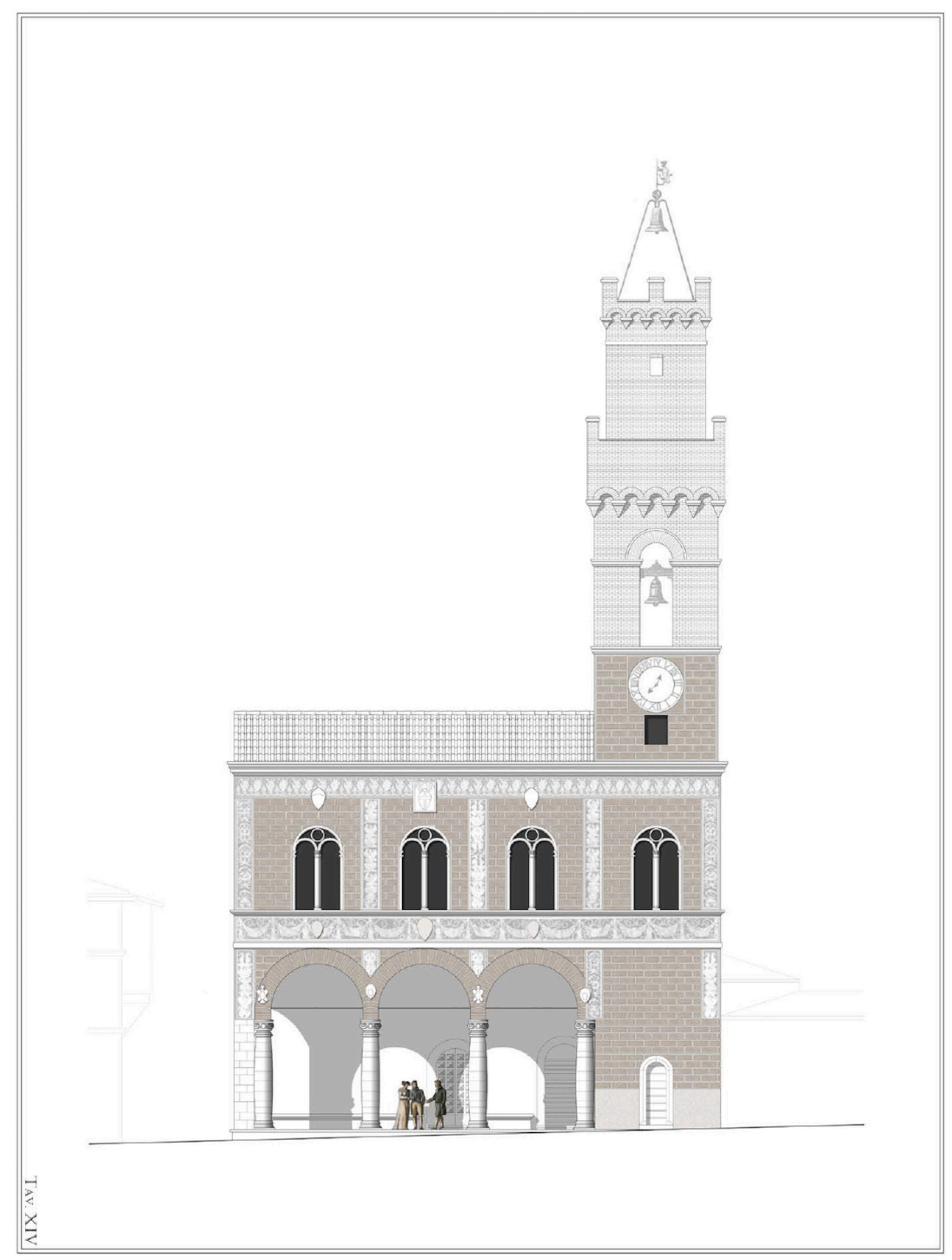


Una serie di ricerche e interventi dedicati allo studio delle facciate graffite, a partire dagli anni '60 del Novecento [Maccari 1960, Errico 1985, Ferragni 1984] ha permesso di recuperare molte partiture originarie, come dimostrano gli esempi dell'edifico di via della Fossa a Roma e del palazzo di Bianca Cappello a Firenze. Tuttavia, nonostante l'importanza quantitativa dei casi conservati o documentati, e l'autorevolezza degli artisti che ne sono stati i protagonisti (Mantegna, Giorgione, Tiziano, Pordenone,Vasari, Polidoro da Caravaggio,Tintoretto, Taddeo Zuccari), questa forma decorativa è tuttora ai margini della storiografia artistica.

L'analisi diretta di questo tipo di decorazione consente di verificare le qualità materiali e i riferimenti formali i cui caratteri stilistici si affermano nell'ambito della rivisitazione rinascimentale della cultura classica [Forcellino 1988, p. I 30]. La simulazione di fregi, ornati e ordini architettonici viene non a caso caratterizzata da una bicromia che sottolinea i diversi partiti decorativi, bicromia ottenuta dalla stesura di un doppio strato di intonaco: il primo strato, scuro, consiste in una colla di carbone composta da una parte di malta di calce colata fine e due parti di inerte di sabbia o pozzolana, a cui si aggiunge carbone di legna polverizzato al mortaio; il secondo strato è un intonachino di calce e sabbia bianca dello spessore di 2-3 mm, steso quando la colla di carbone è ancora umida. Su quest'ultimo strato, attraverso la tecnica dello spolvero, vengono riportati i contorni dei diversi disegni che fanno da traccia per la successiva asportazione dell'intonaco bianco. Così Giorgio Vasari descrive in dettaglio questa tecnica: "Hanno i pittori un'altra sorte di pittura, che è disegno e pittura insieme, e questo si domanda sgraffito, e non serve ad altro che per ornamenti di facciate di case e palazzi, [...]. Restaci ora ragionare de le grottesche che si fanno sul muro, quelle che vanno in campo bianco. Non ci essendo il campo di stucco, per non essere bianca la calce, si dà loro per tutto sottilmente il campo bianco; e fatto ciò, si spolverano e si lavorano in fresco di colori sodi, perché non avrebbono mai la grazia ch'hanno quelle che si lavorano su lo stucco. Di questa spezie possono essere grottesche grosse e sottili, le quali vengono fatte nel medesimo modo che si lavorano le figure a fresco o in muro" [Vasari 1986, pp. 72, 73]. Riportandone il modo di realizzazione e l'utilizzo per la decorazione delle facciate, Vasari sottolinea come il graffito presenti vantaggi come la rapidità di esecuzione e la resistenza alle intemperie, rendendosi adatto per decorazioni esterne. II procedimento indicato da Vasari è questo: sull'intonacato grezzo [3], si stende malta di una parte di calce e due di sabbia o pozzolana, si aggiunge polvere di carbone vegetale che gli conferisce la tipica colorazione
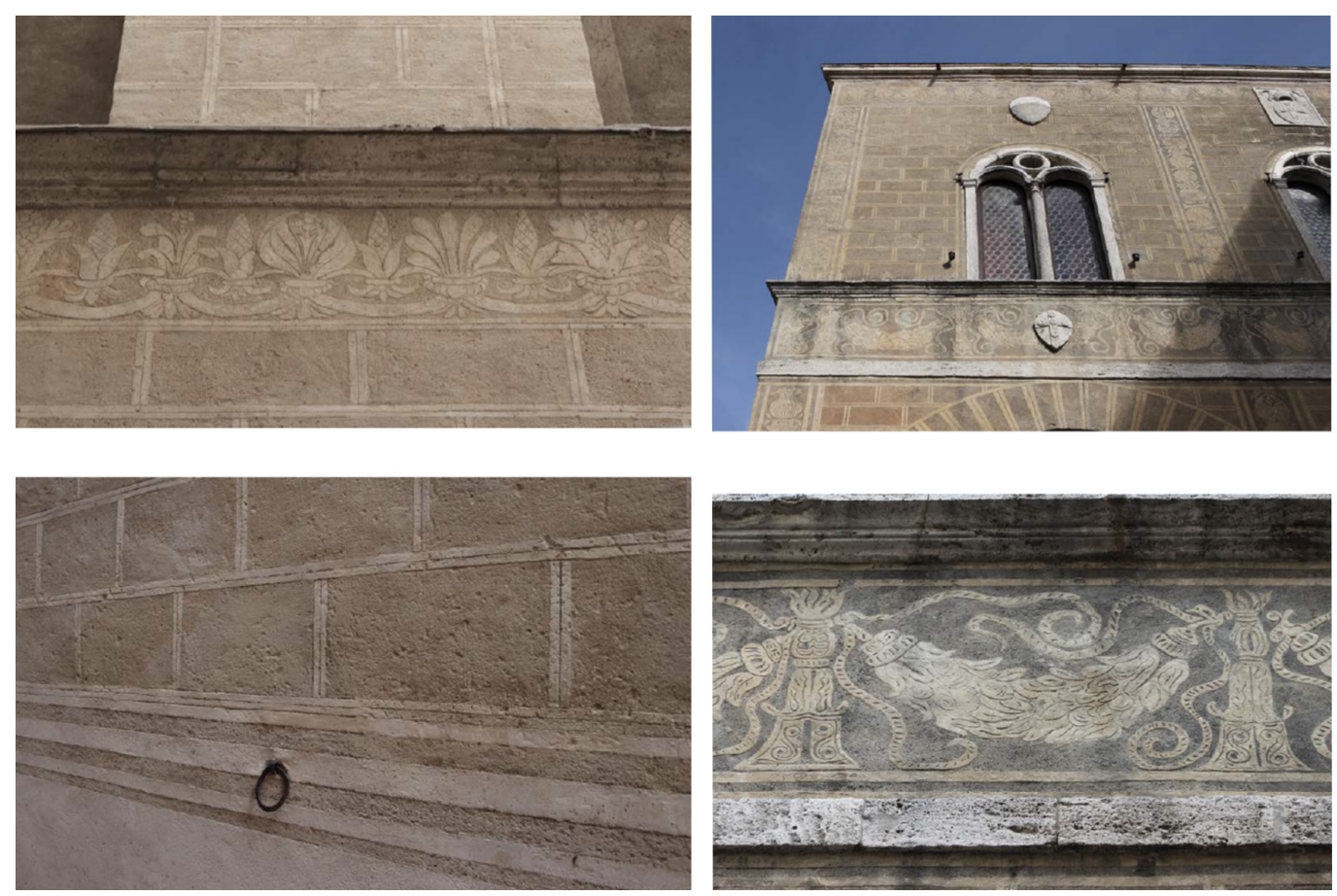
grigio cupo [4]; sopra il primo strato si stendono 2-3 mm di intonaco di calcina di travertino. Quindi, mentre è ancora fresco, si stendono i cartoni dai contorni bucherellati e si trasferisce il segno sulla facciata [5]. Una volta riprodotto il disegno, lo strato superiore è graffiato con strumenti di ferro acuminati, fino a far scomparire lo strato chiaro, rivelando quello sottostante ruvido e scuro. Infine, si completa con effetti di chiaroscuro a pennello [6]. II graffito è così comune nella Firenze del Vasari che non stupisce la menzione nelle Vite [Vasari I986, pp. 72, 73], dove appare nell'introduzione alla Pittura e non all'Architettura, come nel caso di altri mestieri che di diritto sarebbero appartenuti ad ambiti legati alla pietra e alla scultura, allo scalpello piuttosto che al pennello (mosaici, intarsi, niellature ecc.). Può darsi che Vasari, nel dibattito sul primato della pittura o della scultura abbia voluto far pendere la bilancia in favore della sua pittura, associandole altre tecniche di decorazione superficiale. D'altronde nel capitolo appena precedente $(X X V)$ Vasari descrive anche la tecnica del chiaroscuro, con ciò associando alla stessa vocazione figurativa i graffiti bicromi e i chiaroscuri monocromi, volti a dare l'illusione del rilievo. Nel secolo successivo, si assiste all'adozione di intonaci e stucchi a rilievo, tinteggiati per simulare il travertino o alludere al marmo. È possibile mettere in relazione questo mutamento tecnico con il mutamento culturale che cerca di emancipare i materiali dalle connotazioni simboliche classiciste. Nel primo Cinquecento, infatti, l'impiego del travertino - vero o finto - presenta un valore ideologico derivato dall'uso classico, a prescindere dalla funzione costruttiva. II Seicento perde questo rapporto con l'antico e supera il rapporto che la tradizione romana aveva stabilito tra forma e materia: il materiale si esaurisce nella rappresentazione estetica senza più riferimento a un sistema di valori. Eliminata la relazione connotativa con l'antichità, perde valore in seno al complessivo messaggio architettonico.

Uno stucco, che vediamo come la trasformazione di primo grado di una pietra, può essere sostituito da una tinta (una trasformazione di secondo grado). Non a caso, la fase intermedia è testimoniata dall'utilizzo seicentesco di tinte a calce caricate con polvere di travertino o di marmo, un espediente che semplifica la questione materica posta da Bramante, Peruzzi, Raffaello e Sangallo.

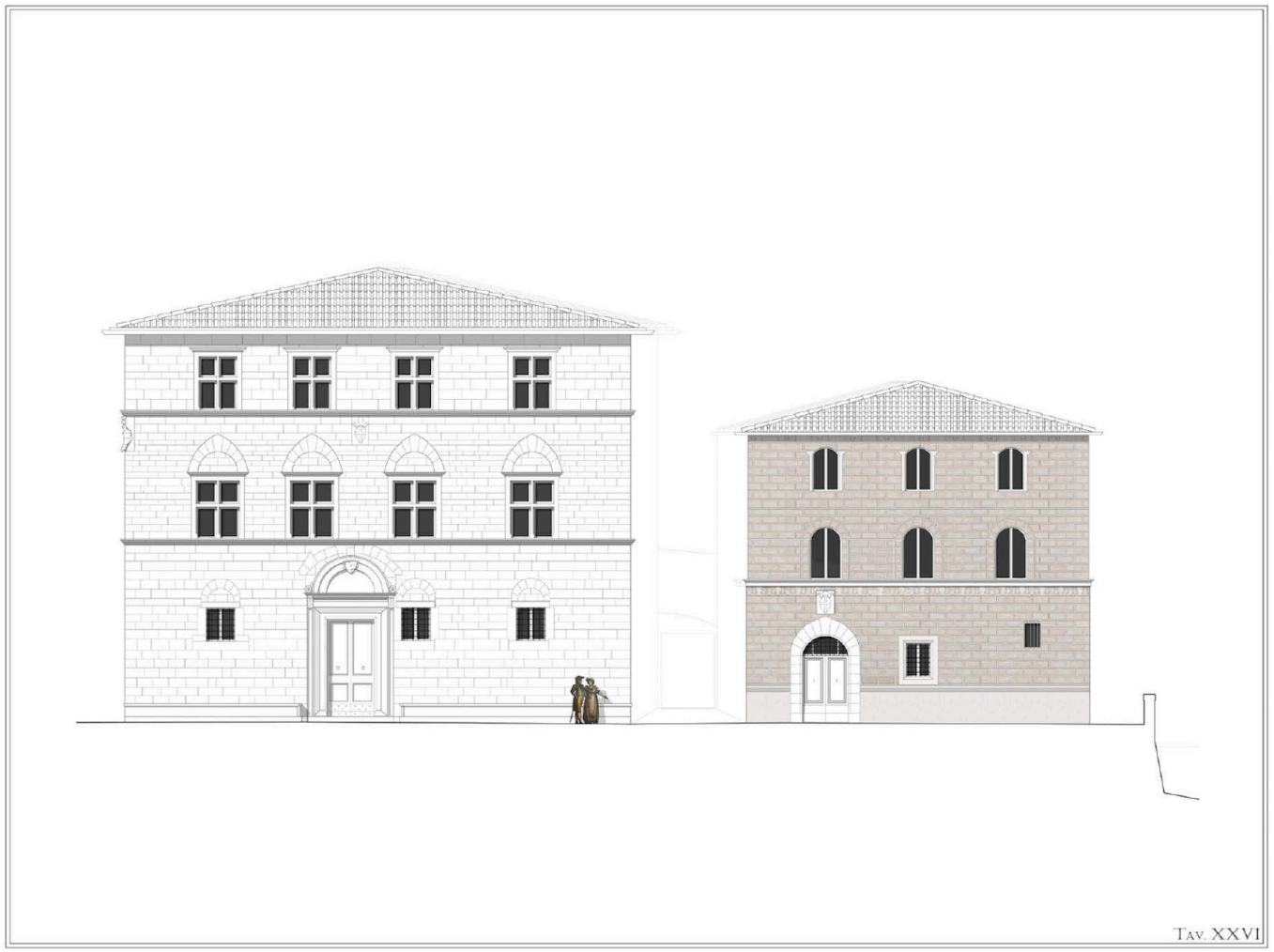


Fig. 8. Pienza, Palazzetti in corso il Rossellino, 85-87, 8I-83, dettagli (fotografie degli autori).
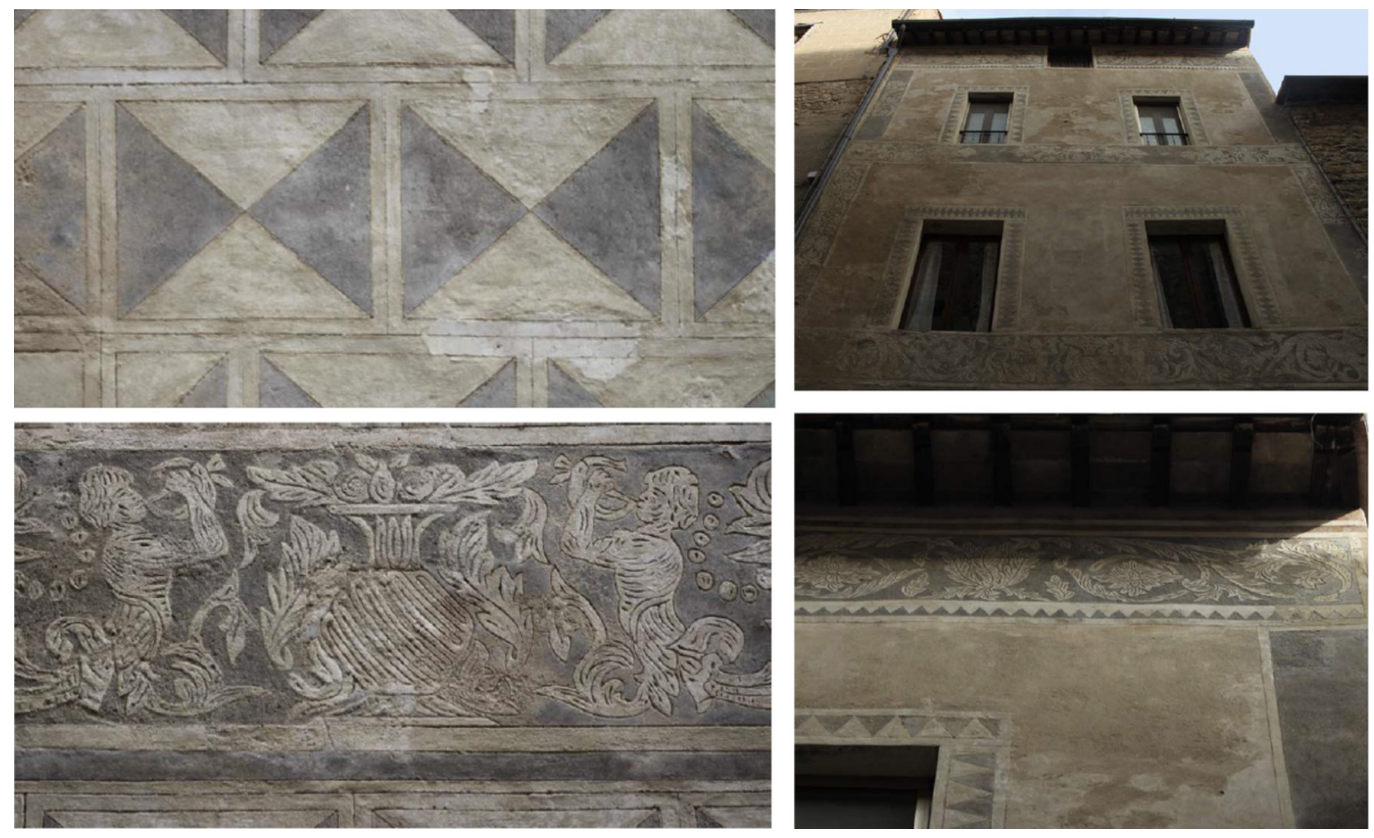

\section{Conclusione}

La disamina della letteratura e della documentazione, della quale parzialmente si è dato conto in questo paper, ha evidenziato come il patrimonio delle facciate di Pienza sia un completo 'testo materiale' per lo studio delle facciate a graffito, anche sotto l'aspetto delle diverse condizioni di manutenzione, ripristino, modifica, o persino distruzione, alle quali essi si presentano (figg. 2-8).

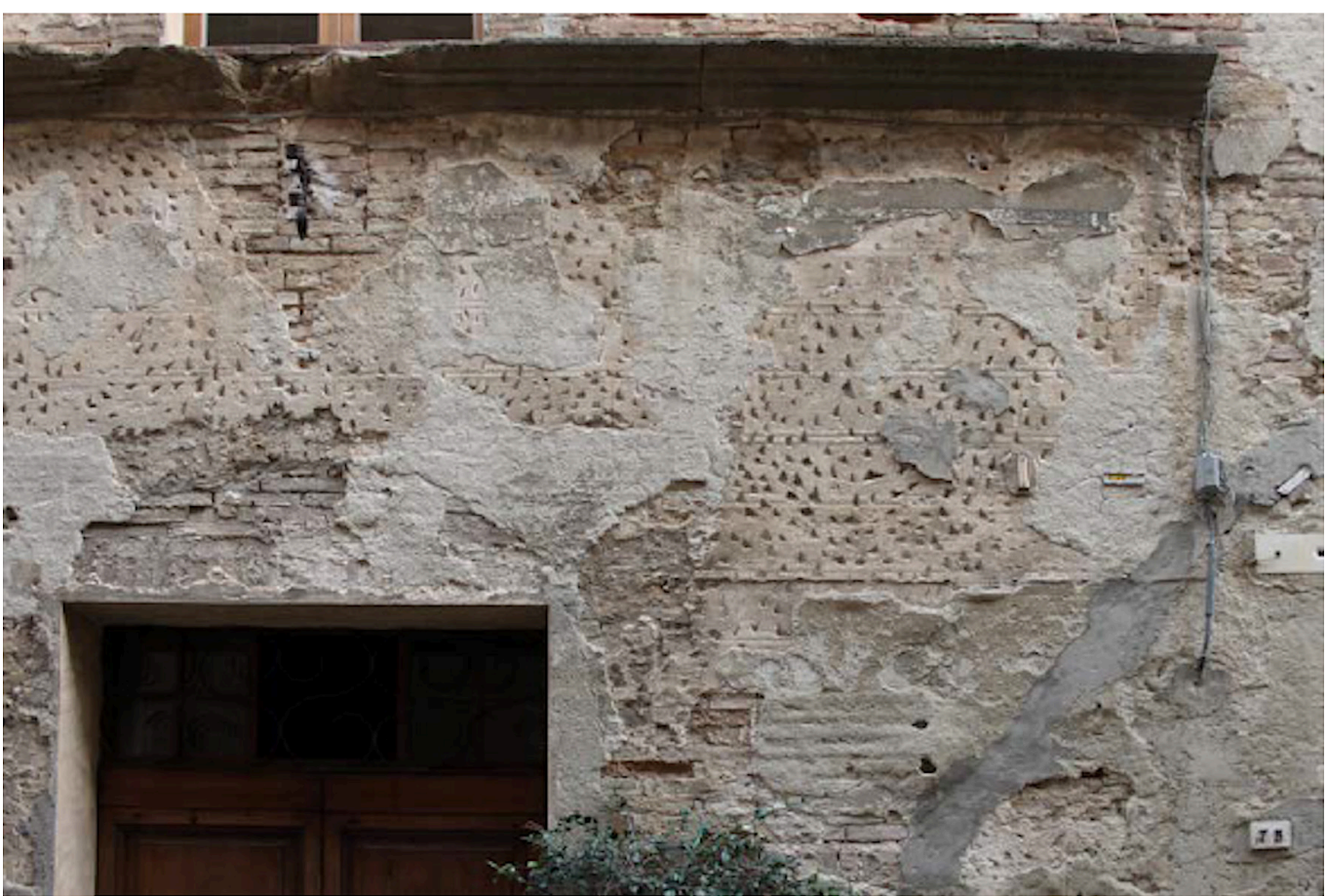




\section{Note}

[I] La constatazione che gli stessi romani avevano usato materiali poveri per contraffarne altri costosi, rendeva legittimo l'uso che ne faranno gli architetti rinascimentali, dal quale traspare il desiderio di competere con la dovizia di materiali che fu del mondo antico.

[2] A.S.R. 1565.

[3] Costituito da rinzaffo e a volte anche con l'aggiunta di arriccio.

[4] I neri usati più frequentemente sono i neri di carbone, ottenuti bruciando ossa, avorio, oli naturali, legno, carte, noccioli di frutta e altri materiali organici; i residui della calcinazione sono poi macinati, lavati e fatti asciugare. Sono pigmenti stabili alla luce e agli agenti chimici, con un medio potere coprente. Cfr. Cortellesi 2014.

[5] La tecnica è entrata in uso dopo l'invenzione della carta (prima cartiera a Fabriano: 1276). Con un sacchetto di garza riempito di pigmento nero si batte a tampone lungo le linee forate, la polvere penetra e lascia una linea puntinata, che può essere resa continua con un colore a pennello. Il foglio dello spolvero è usato più volte, per l'esecuzione di elementi decorativi anche a immagine invertita. Cfr. Cortellesi 2014.

[6] II contrasto chiaroscurale è sottolineato con una tinta di acqua scura. Lo stesso anche sulle parti ombreggiate dei campi chiari soprattutto se i tratti del disegno rappresentano grottesche o motivi vegetali, per dare così un effetto di rilievo.

\section{Riferimenti bibliografici}

Cortellesi Silvia (20 I 4). Le facciate graffite a Roma tra XV e XVI secolo: <www.it.scribd.com/ doc/4809043/graffite-roma>.

Errico Maria, Finozzi Stella Sandra, Giglio Irene (1985). Ricognizione e schedatura delle facciate affrescate e graffite a Roma nei secoli XV e XVI. In Bollettino d'Arte. Roma: Istituto Poligrafico della Zecca dello Stato, pp. 33-34, pp. 53-I 34.

Ferragni Daniela et al. (1984). La conservazione degli intonaci sgraffiti. In Ricerche di Storia dell'Arte, n. 24, pp. 33-43.

Forcellino Antonio (1988). Intonaci e coloriture nel Cinquecento e Seicento: vocazioni espressive e tecniche esecutive. In Bollettino d'Arte. Roma: Istituto Poligrafico della Zecca dello Stato, LXXIII, pp. I 30.

Maccari Enrico, lannoni Giovanni (1960). Graffiti e chiaroscuri esistenti nell'esterno delle case. Roma: Enrico Maccari Incisore ed Editore.

Panofsky Erwin (I999 a). II significato nelle arti visive. Torino: Einaudi, 1999 ( la ed. 1955).

Panofsky Erwin ( 1999 b). Studi di iconologia. I temi umanistici nell'arte del Rinascimento. Torino: Einaudi.

Salerno Rossella (2000). La macchina del disegno: teorie della rappresentazione dell'architettura nel XIX secolo. Antologia critica. Bologna: CLUEB.

Serlio Sebastiano (I584). I sette libri dell'architettura. Venezia: Francesco de' Franceschi.

Ugo Vittorio (199|). I luoghi di Dedalo. Elementi teorici dell'architettura. Bari: Dedalo.

Ugo Vittorio (1996). Architettura ad Vocem: verso un glossario di termini di architettura. Milano: Guerini studio.

Vasari Giorgio (1986). Le vite de' più eccellenti architetti, pittori, et scultori italiani, da Cimabue insino a' tempi nostri. Firenze: Lorenzo Torrentino, I550. (Ried. a cura di Bellosi Luciano e Rossi Aldo. Torino: Einaudi).

Vasari Giorgio (1996). Le tecniche artistiche.Vicenza: Neri Pozzi editore.

\section{Autori}

Daniele Giovanni Papi, Politecnico di Milano, daniele.papi@polimi.it

Franco Forzani Borroni, Politecnico di Milano, francoforzaniborroni@hotmail.com

Francesca Di Geronimo, Politecnico di Milano, francesca.digeronimo@polimi.it

Per citare questo capitolo: Papi Daniele Giovanni, Forzani Borroni Franco, Di Geronimo Francesca (2020). Ornamento a graffito delle facciate. La rappresentazione dell'Architettura sull'Architettura/Graffiti ornament of the façades. The representation of Architecture on Architecture. In Arena A., Arena M., Brandolino R.G., Colistra D., Ginex G., Mediati D., Nucifora S., Raffa P. (a cura di). Connettere. Un disegno per annodare e tessere Atti del $42^{\circ}$ Convegno Internazionale dei Docenti delle Discipline della Rappresentazione/Connecting. Drawing for weaving relationships. Proceedings of the 42th International Conference of Representation Disciplines Teachers. Milano: FrancoAngeli, pp. 752-77I. 


\title{
Graffiti Ornament of the Façades. The Representation of Architecture on Architecture
}

\author{
Daniele Giovanni Papi \\ Franco Forzani Borroni \\ Francesca Di Geronimo
}

Abstract

The complete cataloging of the ornamental graffiti vestments of the palaces of Pienza (fig. I) was preceded by the specific research of the necessary evaluation and cataloging elements. The direct survey and redesign then led to a dissertation (already discussed) and a monograph being edited on the already completed and complete cataloging of the facades of the city. In this paper he explains the preliminary studies conducted.

From literature and documentation it is clear how less frescoed façades were considered in Renaissance Tuscany than graffiti ones, probably due to a greater mastery of the technique by the artists, durability over time and speed of realization. Subsequently, often and inexplicably considered as simple layers of protection, instead of real works of art and architecture, these surfaces were often neglected in maintenance or even covered with uniform plaster. Almost ignored by historiography, the loss of many of them occurred before a proper documentation and safeguarding process was defined, with the sole sensitivity of the owners of the properties to bring with them responsibility and protection burden.

The ultimate hope of the cataloging of the Pienza palaces, in an attempt to lead the theme of the graffiti façade to the possibility of a critical reading, is to bring the topic back to the dignity of a study topic, never explicitly denied, but certainly diminished, over the centuries of inattention (fig. 9).

Keywords

ornament, graffito, Serlio, Vasari, Pienza.

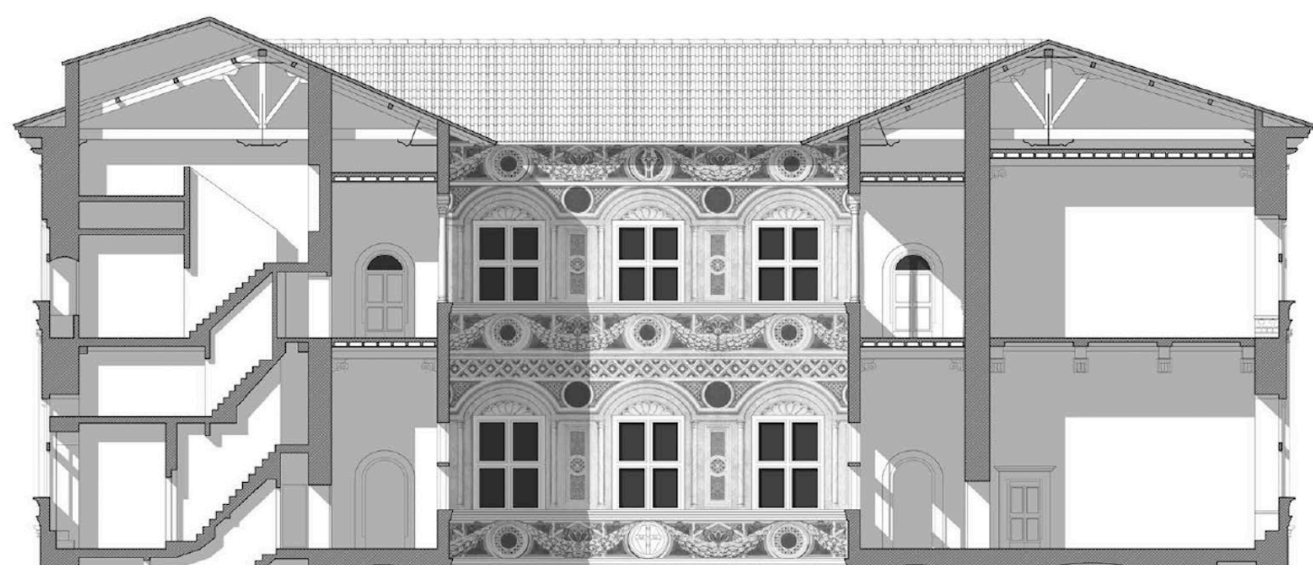




\section{Notes on the ornamentation of facades after the Middle Ages}

From the fifteenth century onwards, the particular care in the execution of the facades became a stable figure, especially in relation to the new urban designs. In this cultural climate, the geometric-formal Tuscan-style vision is enriched with graphic effects up to the synthesis of the late Renaissance, between sculptural plasticity and two-dimensional layer, according to that movement that Panofsky calls the "rebellion of non-architects" [Panofsky 1962, pp. 223, 224].

Color is not intended as a material that covers the facade, but as the element that transforms the building into a reading text intended for the city, testimony to the grandeur and prestige of the family that occupies it.

The iconographic typology is often repeated, as if there is a canon of decoration for subjects. This is actually due to the discovery and diffusion of 'grotesque' motifs, which became fashionable during the Renaissance. Among the painters who study the phenomenon more closely, it is especially the Florentine Filippino Lippi (1457-I504), who between 1487 and 1502 transposed these discoveries into the exuberant decorative structures of his most famous fresco cycles. His footsteps are followed by Andrea di Cosimo Feltrini (I477-I 548) who has the primacy of black and white graffiti for grotesque compositions, in which he combines the formal energy of Filippino and the chiaroscuro vibration of painting ancient. In the second half of the sixteenth century -and always in the Florentine environment- the greatest specialist in the field of this 'old-fashioned' ornament can be considered Bernardino Barbatelli (|548-16|2), nicknamed "Poccetti" from time to time, Bernardino delle Facte or Bernardino delle Grottesche, an artist trained in the circle of Vasari, whose decorative flair is practiced both in the painted grottesca and in the engraved one.

In the seventeenth century, in the wake of the post-conciliar climate, this decoration fell into disuse due to the secular contents. In the last decades of the eighteenth century, with the revival of Pompeian painting, it reappears in forms other than the traditional grotesque,

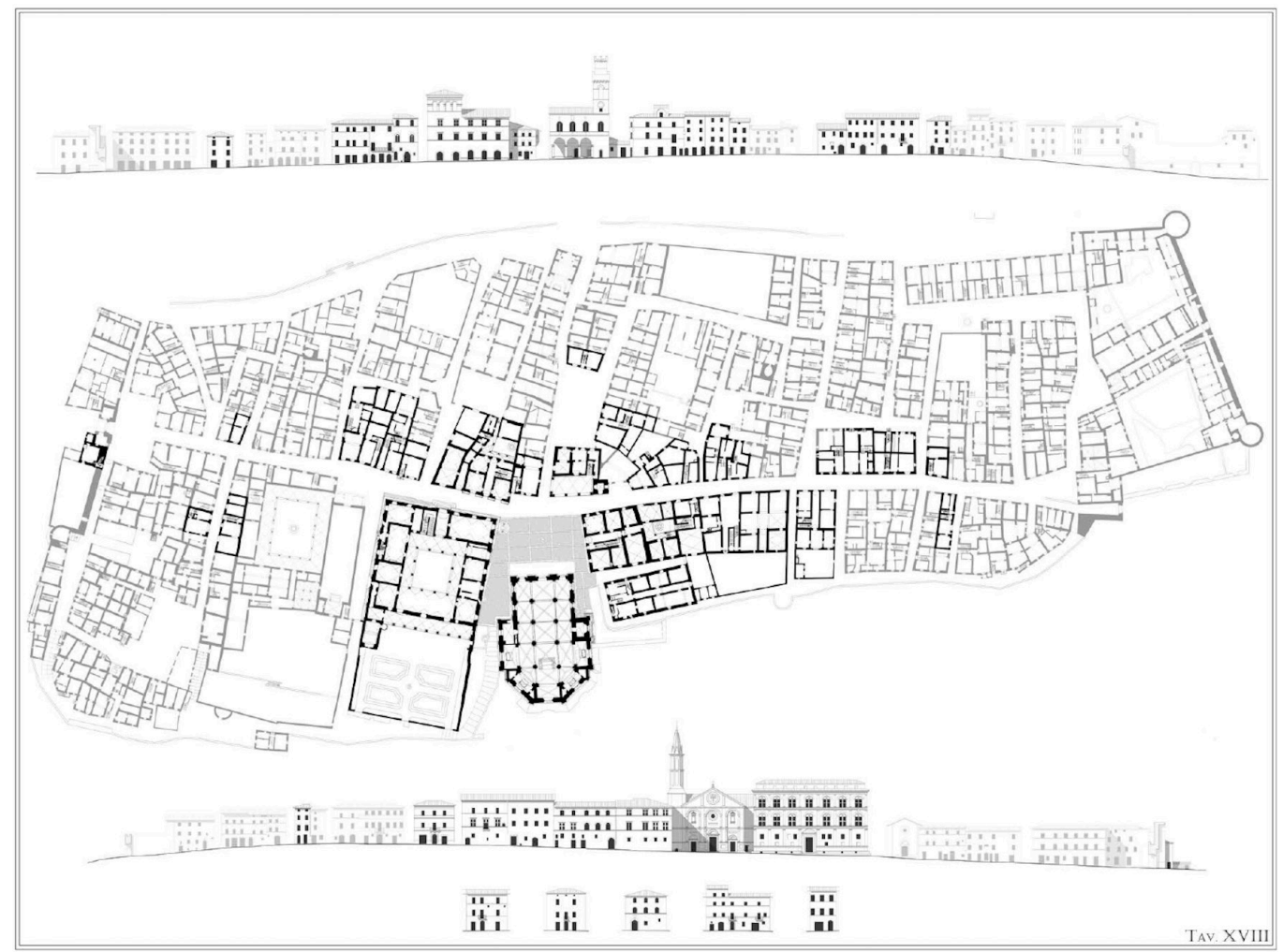


exhibiting iconographic and stylistic fidelity to the originals. Another different version of the grotesque was affirmed during the nineteenth century, in harmony with the historicist instances of Romanticism. With the intention of re-evaluating the past and of proposing its figurative aspects as a symbol of moral and cultural continuity, the nineteenth century resorts to imitating the Renaissance ornaments of the great masters. In cities with a more lively decorative tradition, public and private buildings, banks and offices still offer a vast sample of grotesque compositions dating back to the 19th century.

A final transformation of this decorative genre took place in the second half of the nineteenth century, in correspondence with the development of eclectic architecture, when the reference to traditional models is manifested in the symmetry of the composition, departing from the overall appearance of the decorations.

\section{Surface finishing techniques}

"La figura qui davanti segnata è d'opera corintia la quale in parte si dimanda cruda e confusa in quella parte dove sono le colonne di pietra mista, e oscura perché la cosa di relievo essendo oscura viene a fare contrario effetto sopra la cosa chiara. Per questa ragione gli ottimi pittori dipingendo qualche istoria o favola, dove intervengono più figure, una dopo l'altra, fanno sempre le figure più vicine agli occhi nostri di colore più chiaro per dare più forza all'opera sua. E se altrimenti facessero cioè facendo la figura più vicina di colore oscuro e le più lontane di colore chiaro, e l'opera loro sarebbe cruda e confusa. Ciò avviene nell'opera qui davanti per le ragioni sopradette. Ma non voglio però che l'architetto rifiuti le colonne di pietra mista oscura né di porfido e serpentino, né tante belle e diverse incrostazioni. Anzi se ne serva grandemente ma con buon giudicio" [Serlio 1584, Libro IV, p. I26].

The passage shown, commented on by an illustration of the seventh of Serlio's Books of Architecture, testifies to the interest of Renaissance architects for the material: the use and

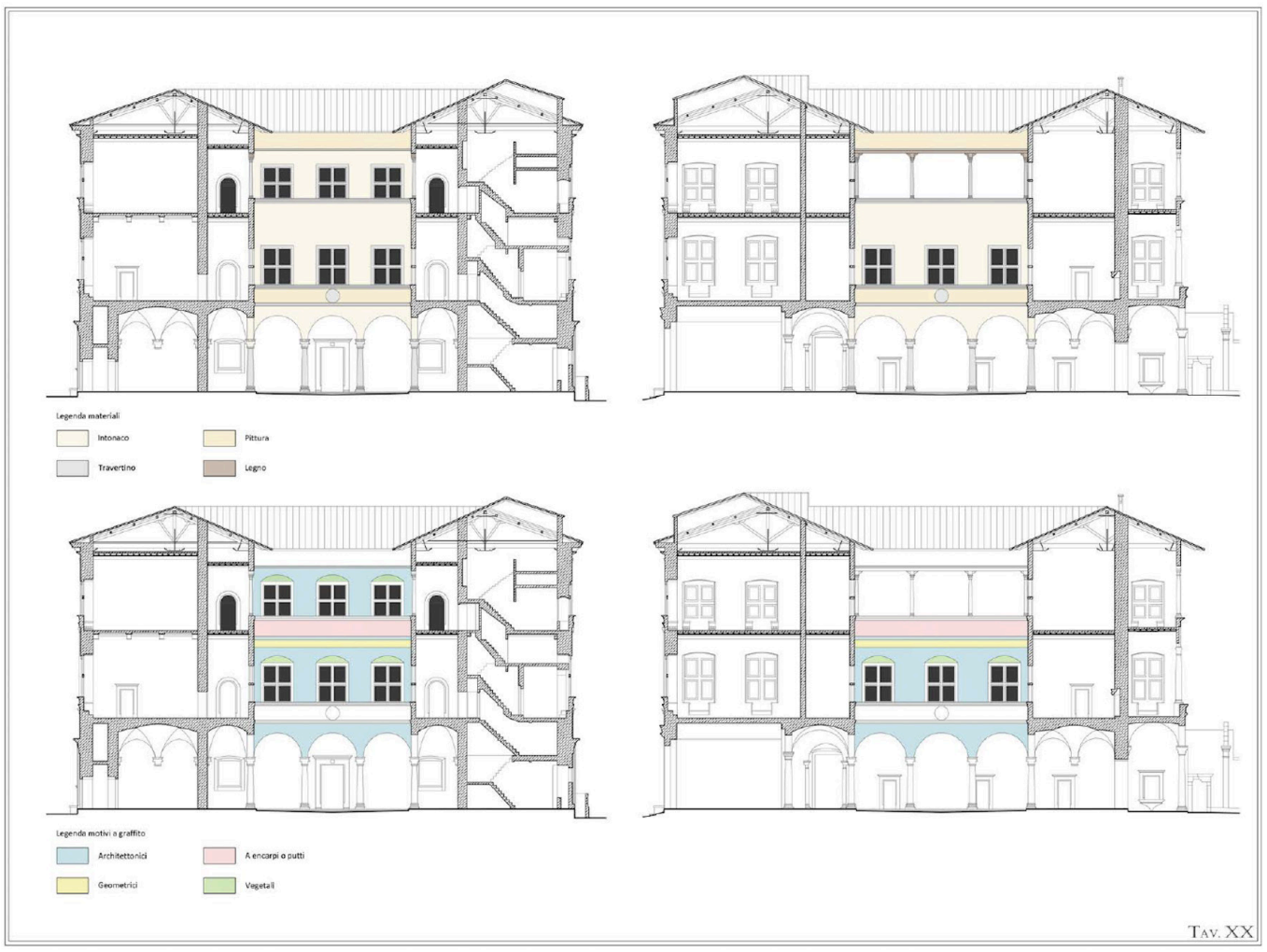


choice of specific materials involves the chromatic-visual definition of the work, directly derived from the intention of its designer. Furthermore, since every aspect of the culture of the sixteenth century must be related to the ancient (and in particular with the knowledge that there was of the ancient at the time), the analysis starts from the studies conducted on the monuments of the past at that time, through the examination of the drawings of Roman antiquities and of the treatises: both show interest both for the construction techniques in general, and for the techniques of imitation and counterfeiting of some materials.

The execution of the designs also records the taste for the appearance of some materials and the systematic concentration of others -the peperino, the tuffs and the bricks- deemed suitable for an exclusively constructive role [I]. From the re-proposition of the taste of the ancient Romans, the re-nascent aspiration of a stone architecture arises and -where the use of brick masonry replaces the concrete- it is up to the plaster to give the impression of constructive and aesthetic unity: the surface coating no longer possesses only a protective function, as in the Middle Ages, but becomes an integral part of the facade design, imitating stone or other architectural elements. On the plaster, among other things, it is not necessary to apply coloring, in some cases it is the signs of the step, the block or block stapling, which make the imitation of the stone credible. Thanks to such expedients, the expressive needs of architecture take advantage of a new technical synthesis that realizes only the parts of the order in stone, then inserting them in the brick curtains -economically more convenientand finally counterfeiting them with the surface coating.

Some documents found and studied over time have suggested that the brick curtain with which Bramante created the Belvedere courtyard was originally covered with stucco: a drawing attributed to Pirro Ligorio and kept at the Institute of Archeology and Art History of Rome [Forcellino 1988], shows the facades of the courtyard covered by an ashlar that is supposed to be stucco. The documents relating to the construction of part of this coating are deposited in the State Archive of Rome, of which no sign remains today, in which you 
can read: "M.ro Raffaello da Sangallo stuccatore deve adi 2 di giugno I 565 sc. Ottanta havutone mandato a buon conto del lavoro di stucco cominciato da lui nell'emiciclo di belvedere [... a alla cornice dorica del primo ordine che continua el corritore vecchio et nella faccia di muro sopra i podi circolari"' [2].

Among the brick curtains covered with fake stone stucco there could also be those of the Palazzo della Cancelleria, which in a design by Alessandro Specchi appears with the facades covered with ashlar. This coating may have been made of stucco only on the sides of the building -less visible- where the main facade was made of real travertine.

Even the Farnesina by Baldassarre Peruzzi could be read in a different way, if we assumed a light layer of fake stone laid on the pilasters that today appear to be made up of bricks only: the desired display of the construction elements is in fact unlikely, especially considering the contempt for the brick that Peruzzi noted several times in his drawings. It could therefore be argued that the presence of curtain walls does not exclude the possibility that, to finish them, there was the representation of an architecture made of living stone. As for the built in ordinary masonry instead, there is no doubt that its finish was plaster, which in these cases became indispensable.

\section{The graffiti}

Graffiti or painted facades played a predominant role in defining the Renaissance urban scene. Serlio explains how these techniques were aimed at imitation: "Ma se con giudicio saldo si vorrà ornar con i pennelli una facciata si potrà fingere di marmo o d'altra pietra, sculpendo in essa ciò che si vorrà" [Serlio I584, Libro IV, p. 192].

The graffitied and painted facades are between the fifteenth and seventeenth centuries one of the most representative manifestations of Italian artistic culture, which characterizes, with different declinations, the urban landscape of cities such as Rome, Florence, Genoa, Trento, Verona, Mantua, Pienza.
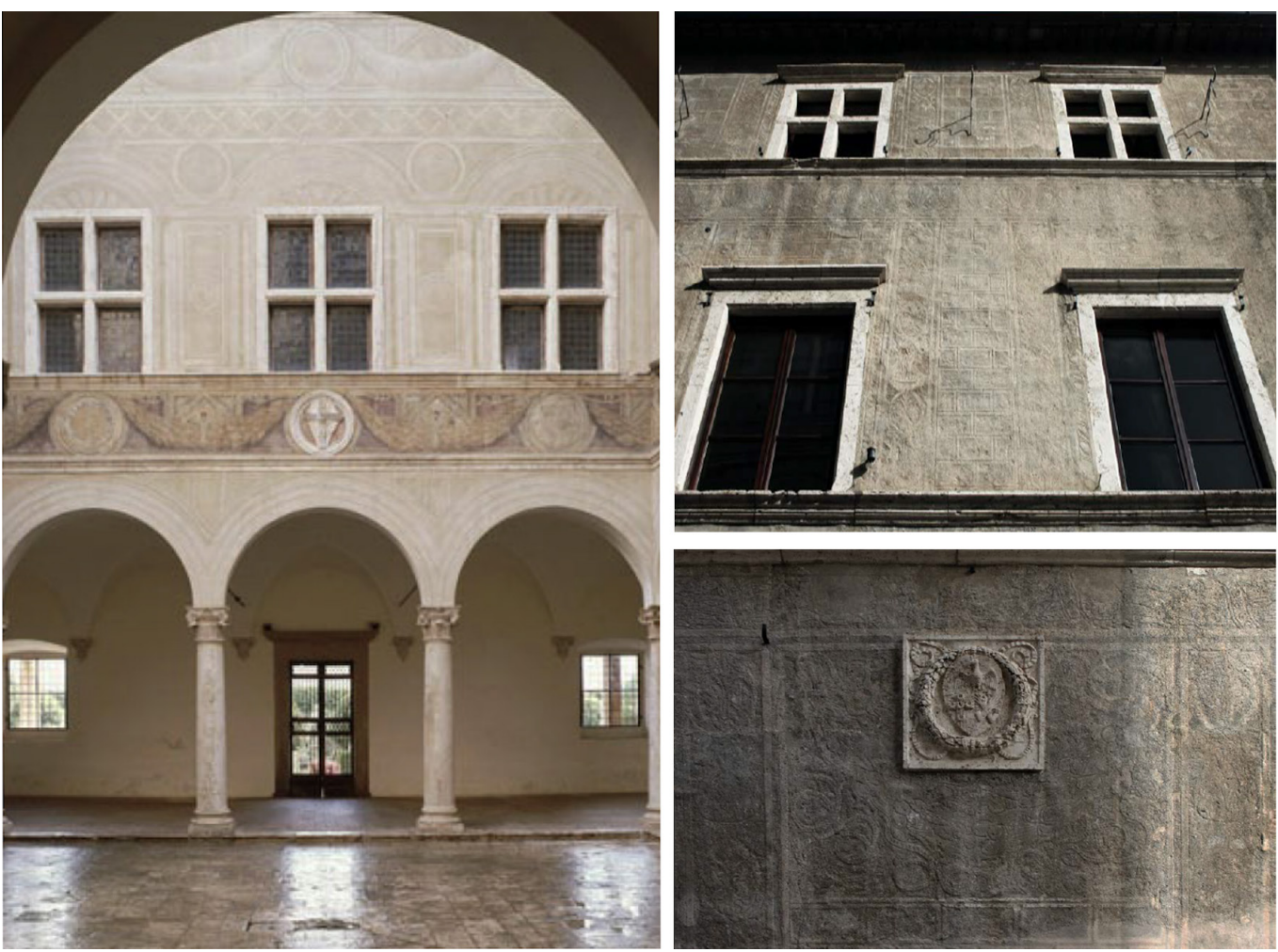
In his first treatise of 1537, Serlio cites painted facades, but presents them as cheap alternatives of stone facades [Serlio I584, Libro IV, pp. 192, 193], thereby condemning them to the role of Architekturersatz, architectural elements of no particular value. According to the author, the painting harms the perception of the massiveness of the walls, which seem to become transparent and disappear, and advises against painting in color, recommends chiaroscuro and refers to grisaille painting, which imitates marble, stone and bronze, and improves the plastic effect of the facade. It admits the representation of festoons of leaves, flowers and fruit, trophies of weapons and triumphal apparatuses that could hang on the walls. Color is not allowed, unless the objects represented are removable, for example fabrics attached to the wall, on which you could paint without disturbing the architectural order.These are in fact the reasons for most of the graffiti decoration, which however Serlio does not mention.

In Florence, and in Tuscany in general, the graffiti facade has constant popularity. More common outside Tuscany is chiaroscuro, similar to graffiti and generally associated with Polidoro da Caravaggio (I499/I500-I543) and Maturino da Firenze (I 490-I528), which made it a fashion in Rome before the sack of 1527, and which becomes obsolete after the death of Polidoro.

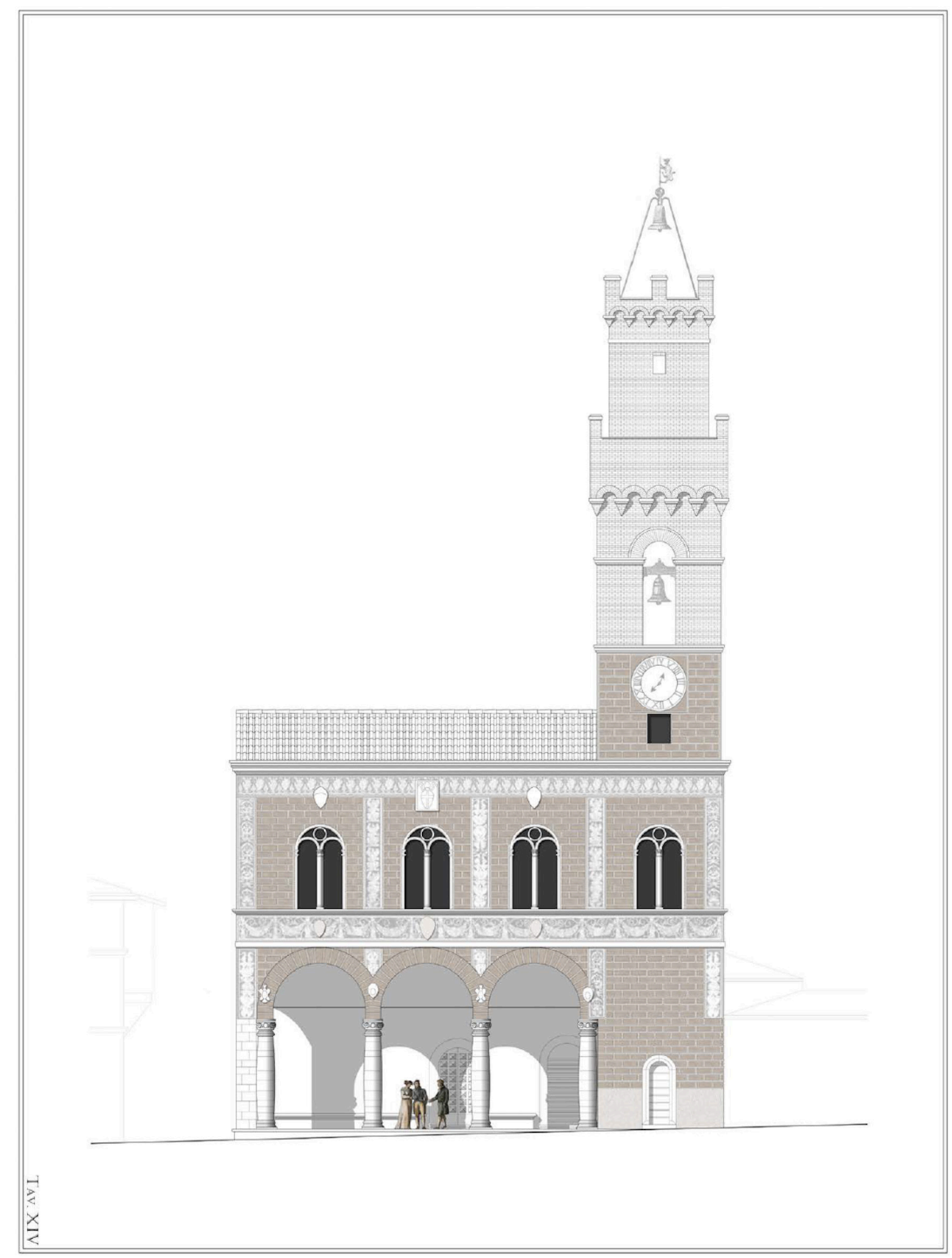


Nonetheless, this variant of painted grisaille facade, essentially figurative, is not successful in Florence, or at least no more than the painted facades (Palazzo Mellini-Fossi and Palazzo dell'Antella). For centuries, the preferred choice of the Tuscans is the graffiti facade.

A series of researches and interventions dedicated to the study of graffiti facades, starting from the 60s of the twentieth century [Maccari 1960, Errico 1985, Ferragni 1984], allowed to recover many original scores, as shown by the examples of the building in via della Fossa in Rome and the palace of Bianca Cappello in Florence. However, despite the quantitative importance of the cases preserved or documented, and the authoritativeness of the artists who were the protagonists (Mantegna, Giorgione, Tiziano, Pordenone, Vasari, Polidoro da Caravaggio,Tintoretto, Taddeo Zuccari), This form of corative is still on the margins of artistic historiography.

The direct analysis of this type of decoration allows to verify the material qualities and the formal references whose stylistic characteristics are affirmed in the context of the Renaissance revisitation of classical culture [Forcellino 1988, p. I 30]. The simulation of friezes, ornaments and architectural orders is not by chance characterized by a duotone that underlines the different decorative parties, duotone obtained by the laying of a double layer of plaster: the first layer, dark, consists of a carbon glue composed of a part of lime mortar, fine casting and two parts of sand or pozzolan aggregate, to which pulverized charcoal is added to the mortar; the second layer is a lime and white sand plaster 2-3 mm thick, applied when the carbon glue is still wet. On this last layer, through the dusting technique, the contours of the different drawings are reported which act as a trace for the subsequent removal of the white plaster. This is how Giorgio Vasari describes this technique in detail: "Hanno i pittori un'altra sorte di pittura, che è disegno e pittura insieme, e questo si domanda sgraffito, e non serve ad altro che per ornamenti di facciate di case e palazzi, [...]. Restaci ora ragionare de le grottesche che si fanno sul muro, quelle che vanno in campo bianco. Non ci essendo il campo di stucco, per non essere bianca la calce, si dà loro per tutto sottilmente il campo bianco; e fatto ciò, si spolverano e si lavorano in fresco di colori sodi, perché non avrebbono mai la grazia ch'hanno quelle che si lavorano su lo stucco. Di questa spezie possono essere grottesche grosse e sottili, le quali vengono fatte nel medesimo modo che si lavorano le figure a fresco o in muro" [Vasari 1986, pp. 72, 73].
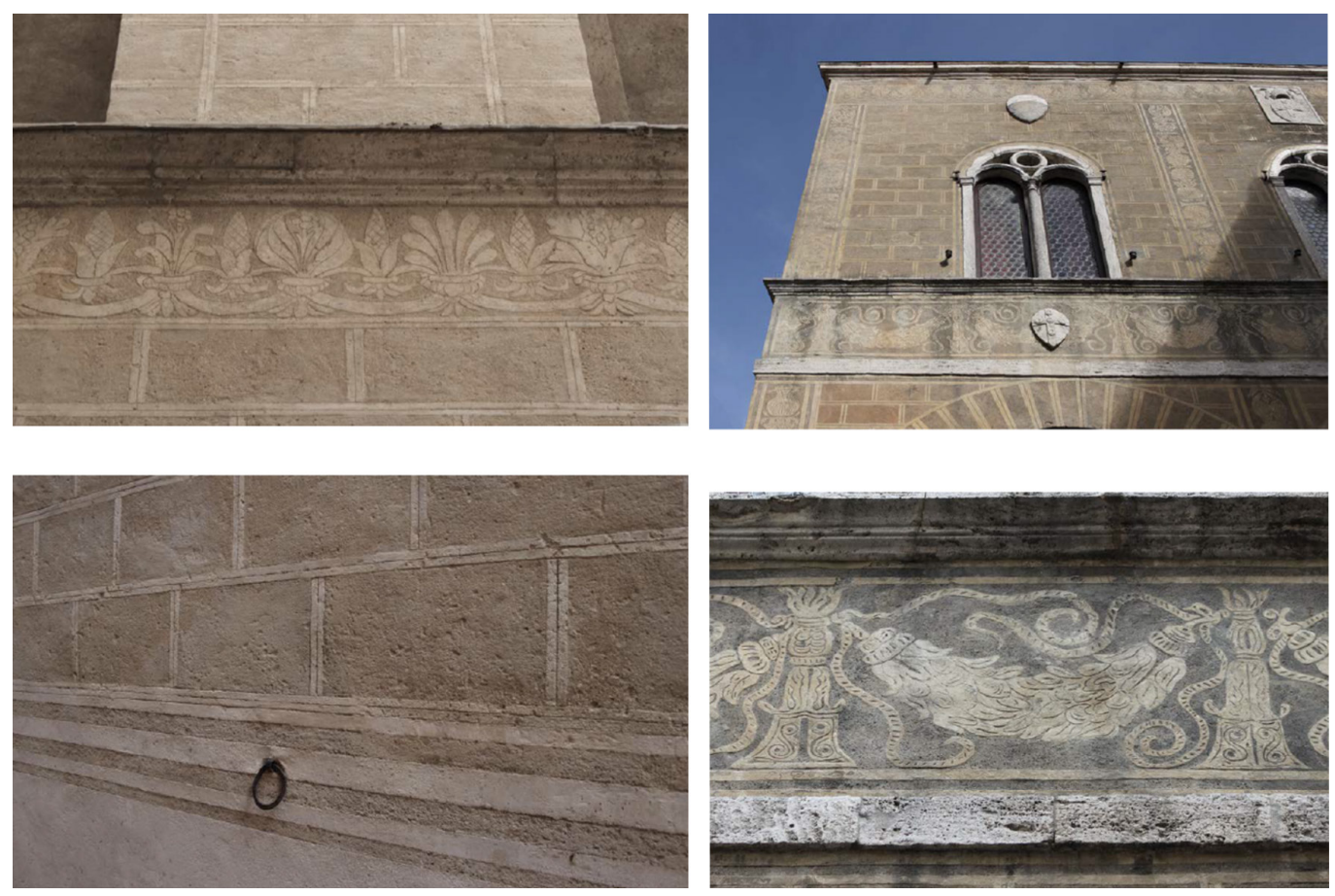
Reporting the way of realization and use for the decoration of the facades,Vasari underlines how the graffiti has advantages such as the speed of execution and the resistance to bad weather, making it suitable for external decorations. The procedure indicated by Vasari is this: on the rough plaster [3], mortar of a part of lime and two of sand or pozzolan is spread, vegetable carbon powder is added which gives it the typical dark gray color [4]; 2-3 mm of travertine mortar plaster are spread over the first layer. Then, while it is still fresh, the cartons are laid out with pitted outlines and the sign is transferred to the facade [5]. Once the design is reproduced, the upper layer is scratched with sharp iron tools, until the light layer disappears, revealing the rough and dark underlying one. Finally, it is completed with brushed chiaroscuro effects [6]. Graffiti is so common in Vasari's Florence that the mention in the Vite [Vasari 1986, pp. 72,73] is not surprising, where it appears in the introduction to Pittura and not to Architettura, as in the case of other professions that by right would have belonged to areas related to stone and sculpture, at the chisel rather than at the brush (mosaics, inlays, niellings etc.).

It may be that Vasari, in the debate on the primacy of painting or sculpture, wanted to tip the balance in favor of his painting, associating it with other techniques of surface decoration. On the other hand, in the chapter just preceding $(X X V)$ Vasari also describes the chiaroscuro technique, thereby associating bicoloured graffiti and monochrome chiaroscuro with the same figurative vocation, aimed at giving the illusion of relief. In the following century, we witness the adoption of relief plasters and stuccos, painted to simulate travertine or allude to marble. It is possible to relate this technical change to the cultural change that seeks to emancipate materials from classicist symbolic connotations. In the early sixteenth century, in fact, the use of travertine - real or fake - had an ideological value derived from the classic use, regardless of the constructive function. The seventeenth century loses this relationship with the ancient and exceeds the relationship that the Roman tradition had established between form and matter: the material runs out in the aesthetic representation without reference to a system of values. Once the connotative relationship with antiquity has been eliminated, it loses value within the overall architectural message.

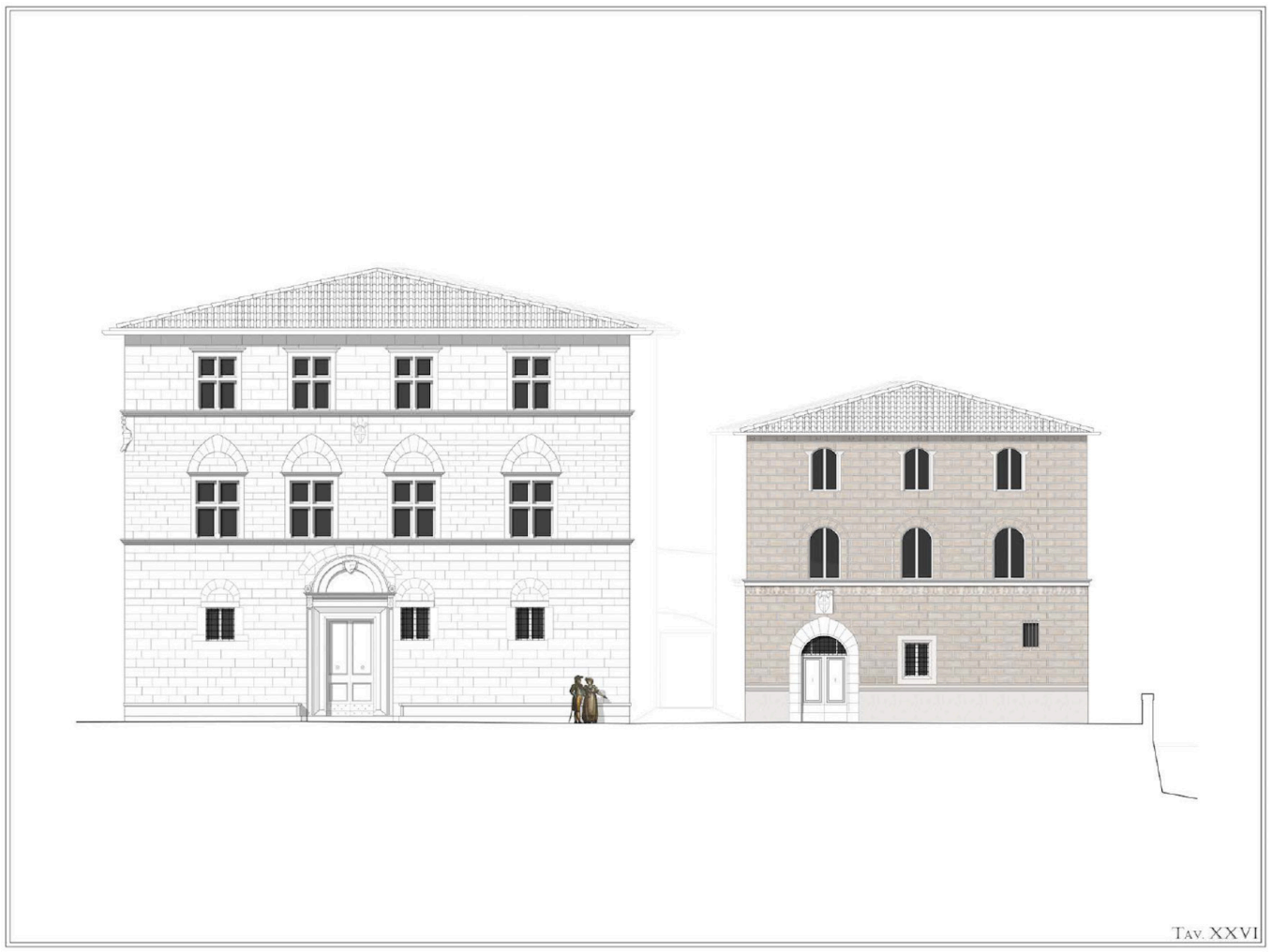


Fig. 8. Pienza, Palazzetti in corso il Rossellino, 85-87, $8 \mid-83$, details (photos by the authors).
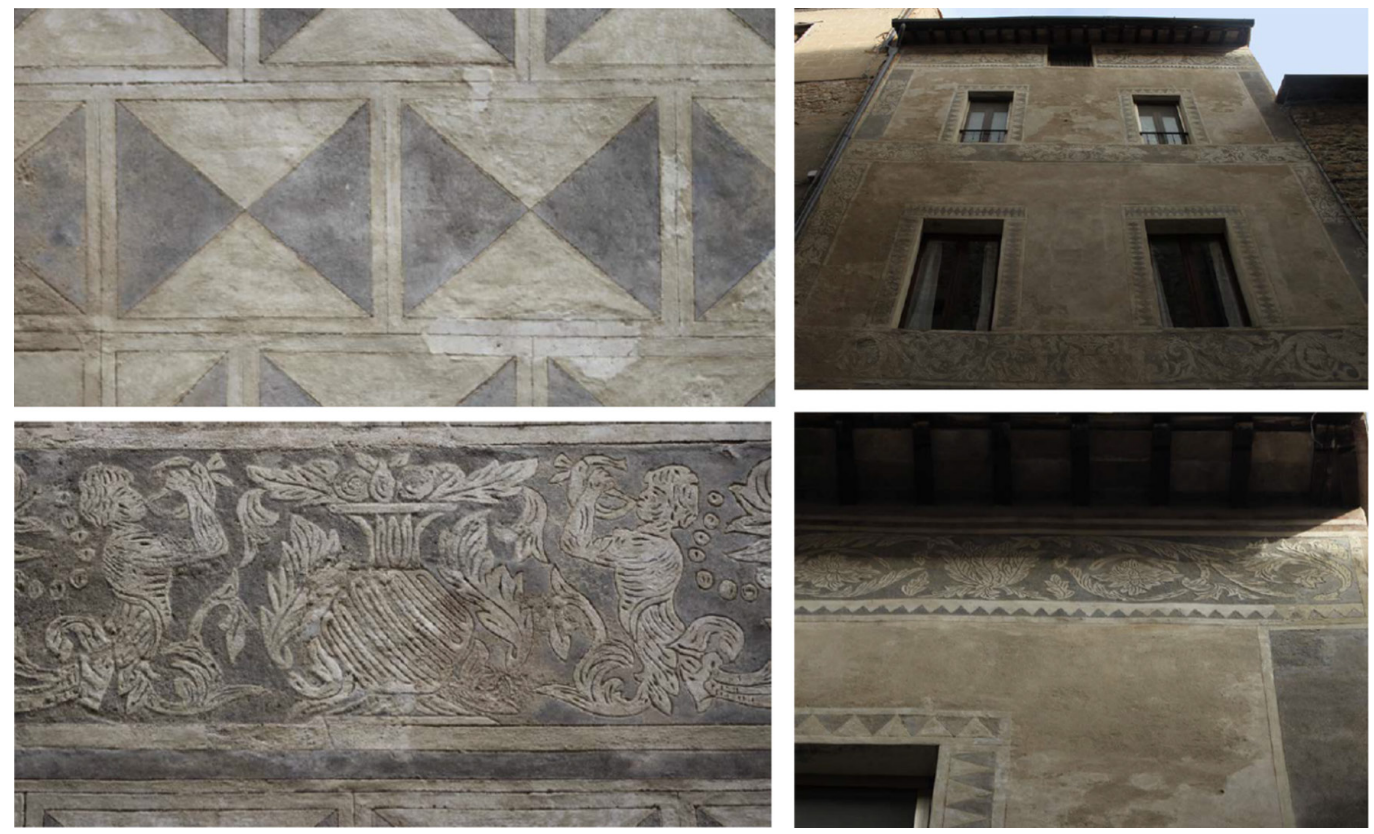

A grout, which we see as the first degree transformation of a stone, can be replaced by a tint (a second degree transformation). Not surprisingly, the intermediate phase is evidenced by the use of seventeenth-century lime paints loaded with travertine or marble powder, a device that simplifies the matter of matter posed by Bramante, Peruzzi, Raffaello and Sangallo.

\section{Conclusion}

The examination of the literature and documentation, which has been partially accounted for in this paper, has highlighted how the patrimony of the Pienza facades is a complete material text for the study of the graffiti facades, also under the aspect of the different conditions of maintenance, restoration, modification, or even destruction, to which they occur (figs. 2-8).

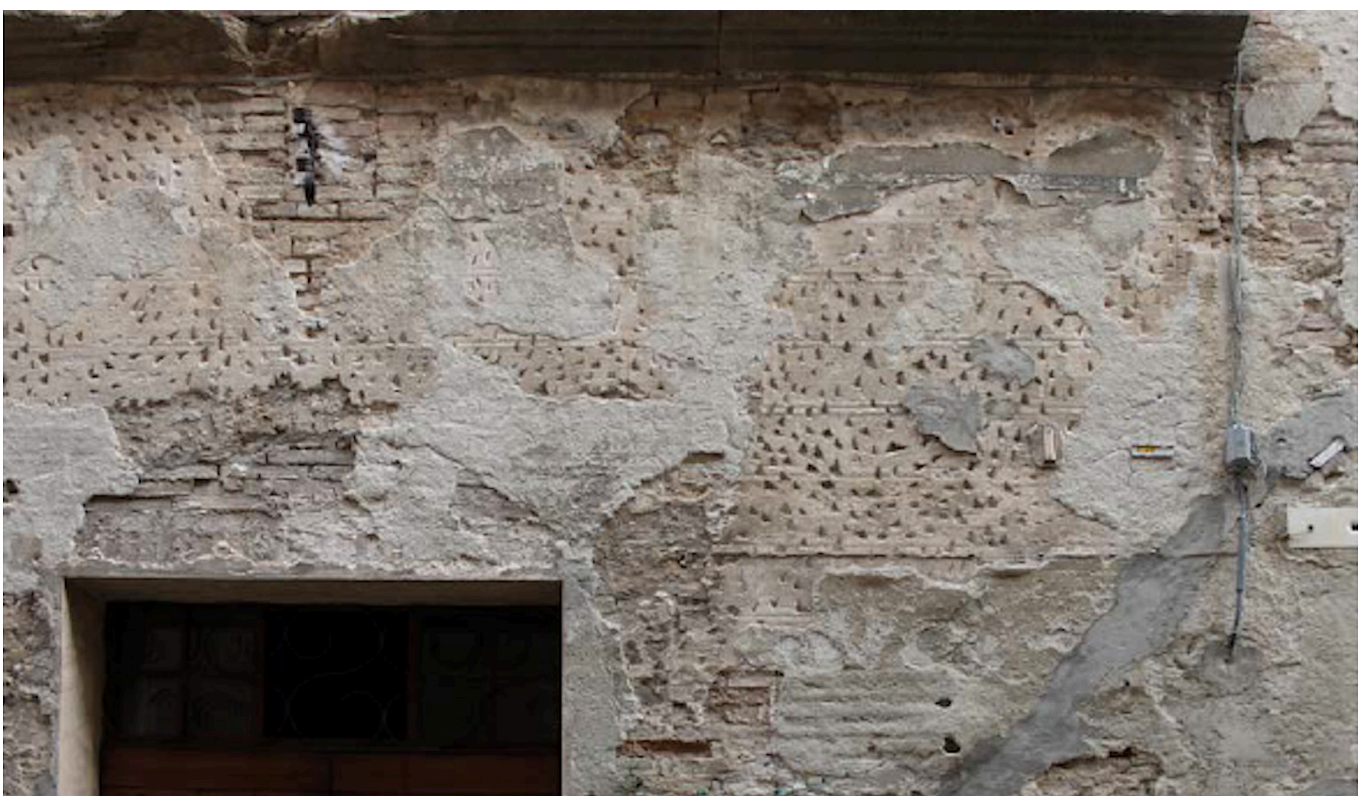




\section{Notes}

[I] The finding that the Romans themselves had used poor materials to counterfeit other expensive ones, made legitimate the use that Renaissance architects would make of them, from which the desire to compete with the wealth of materials that was of the ancient world shines through.

[2] A.S.R. 1565.

[3] Made up of rough coat and sometimes also with the addition of curl.

[4] The blacks most frequently used are carbon blacks, obtained by burning bones, ivory, natural oils, wood, papers, fruit stones and other organic materials; calcination residues are then ground, washed and dried. They are pigments stable to light and chemical agents, with a medium covering power. See: Cortellesi 2014.

[5] The technique came into use after the invention of the paper (first paper mill in Fabriano: I276). With a bag of gauze filled with black pigment, it is swabbed along the perforated lines, the dust penetrates and leaves a dotted line, which can be made continuous with a brush color. The dusting sheet is used several times, for the execution of decorative elements even with an inverted image. See: Cortellesi 2014.

[6] The chiaroscuro contrast is underlined with a tint of dark watercolour. The same also on the shaded parts of the light fields, especially if the features of the drawing represent grotesques or plant motifs, thus giving a prominent effect.

\section{References}

Cortellesi Silvia (20 I 4). Le facciate graffite a Roma tra XV e XVI secolo: <www.it.scribd.com/ doc/4809043/graffite-roma>.

Errico Maria, Finozzi Stella Sandra, Giglio Irene (1985). Ricognizione e schedatura delle facciate affrescate e graffite a Roma nei secoli XV e XVI. In Bollettino d'Arte. Roma: Istituto Poligrafico della Zecca dello Stato, pp. 33-34, pp. 53- I 34.

Ferragni Daniela et al. (1984). La conservazione degli intonaci sgraffiti. In Ricerche di Storia dell'Arte, n. 24, pp. 33-43.

Forcellino Antonio (1988). Intonaci e coloriture nel Cinquecento e Seicento: vocazioni espressive e tecniche esecutive. In Bollettino d'Arte. Roma: Istituto Poligrafico della Zecca dello Stato, LXXIII, pp. I 30.

Maccari Enrico, lannoni Giovanni (1960). Graffiti e chiaroscuri esistenti nell'esterno delle case. Roma: Enrico Maccari Incisore ed Editore.

Panofsky Erwin (I999 a). II significato nelle arti visive. Torino: Einaudi, 1999 ( la ed. 1955).

Panofsky Erwin ( 1999 b). Studi di iconologia. I temi umanistici nell'arte del Rinascimento. Torino: Einaudi.

Salerno Rossella (2000). La macchina del disegno: teorie della rappresentazione dell'architettura nel XIX secolo. Antologia critica. Bologna: CLUEB.

Serlio Sebastiano (I584). I sette libri dell'architettura. Venezia: Francesco de' Franceschi.

Ugo Vittorio (199|). I luoghi di Dedalo. Elementi teorici dell'architettura. Bari: Dedalo.

Ugo Vittorio (1996). Architettura ad Vocem: verso un glossario di termini di architettura. Milano: Guerini studio.

Vasari Giorgio (1986). Le vite de' più eccellenti architetti, pittori, et scultori italiani, da Cimabue insino a' tempi nostri. Firenze: Lorenzo Torrentino, I550. (Ried. a cura di Bellosi Luciano e Rossi Aldo. Torino: Einaudi).

Vasari Giorgio (1996). Le tecniche artistiche.Vicenza: Neri Pozzi editore.

\section{Authors}

Daniele Giovanni Papi, Politecnico di Milano, daniele.papi@polimi.it

Franco Forzani Borroni, Politecnico di Milano, francoforzaniborroni@hotmail.com

Francesca Di Geronimo, Politecnico di Milano, francesca.digeronimo@polimi.it

To cite this chapter: Papi Daniele Giovanni, Forzani Borroni Franco, Di Geronimo Francesca (2020). Ornamento a graffito delle facciate. La rappresentazione dell'Architettura sull'Architettura/Graffiti ornament of the façades. The representation of Architecture on Architecture. In Arena A., Arena M., Brandolino R.G., Colistra D., Ginex G., Mediati D., Nucifora S., Raffa P. (a cura di). Connettere. Un disegno per annodare e tessere. Atti del $42^{\circ}$ Convegno Internazionale dei Docenti delle Discipline della Rappresentazione/Connecting. Drawing for weaving relationships. Proceedings of the 42th International Conference of Representation Disciplines Teachers. Milano: FrancoAngeli, pp. 752-771. 